\title{
C reactive protein concentrations in cystic fibrosis
}

\author{
R E MORETON AND C R KENNEDY
}

Department of Child Health, Southampton General Hospital, Southampton

SUMMARY Serum concentrations of $C$ reactive protein were measured in a cross sectional study of 36 patients with cystic fibrosis and correlated with clinical and radiological assessments. C reactive protein concentration was highly correlated with the Shwachman clinical evaluation score, forced vital capacity as a percentage of the predicted value, and the Chrispin-Norman $x$ ray score. $\mathrm{C}$ reactive protein may be a useful objective index of severity of disease in patients with cystic fibrosis.

$\mathrm{C}$ reactive protein is an acute phase protein whose concentration in the serum rises as much as 1000 fold during the acute phase response. ${ }^{1} \mathrm{~A}$ raised concentration of serum $\mathrm{C}$ reactive protein is unequivocal evidence of an active tissue damaging process and is related both to the severity of the tissue injury and to the type of inflammatory stimulus. For example, large increases occur frequently in bacterial but not in viral infections. ${ }^{2}{ }^{3}$ Its potential clinical usefulness had been explored in neonatal meningitis, septicaemia, postoperative infections, shunt infections, pyelonephritis, rheumatoid arthritis, and Crohn's disease. ${ }^{24}$ It has also been advocated as a screening test for bacterial infections in febrile children. ${ }^{3}$ We report here on serum $C$ reactive protein concentrations in patients with cystic fibrosis and consider its potential use as an index of the severity of the disease.

\section{Patients and methods}

$\mathrm{C}$ reactive protein concentrations were measured in patients with cystic fibrosis and healthy children in a cross sectional study over a four month period. Fifty healthy afebrile children (age range $0 \cdot 03-16 \cdot 1$ years, median: 6.7 years) who were undergoing day surgery (circumcision, eight; herniorrhaphy, 10; orchidopexy, seven; urethroscopy, three; cystoscopy, four; anal stretch, two; others, 16) were studied to establish a reference range for $C$ reactive protein. A blood sample was taken preoperatively after induction of anaesthesia and $\mathrm{C}$ reactive protein was measured quantatively by an enzyme linked immunosorbent assay (ELISA).

Thirty six patients with cystic fibrosis were assessed during either a routine outpatient clinic appointment or an admission to hospital. Each patient was assessed clinically using: (1) Shwachman clinical evaluation score, which is comprised of four categories: general activity, physical examination, general nutrition, and chest radiography findings. ${ }^{5}$ A maximum score of 100 points is possible and decreases as the disease worsens. (2) ChrispinNorman $x$ ray score in which the chest radiograph is divided into four zones each of which is scored according to the type of shadows visible on $x$ ray. ${ }^{6}$ Chest configuration is also assessed. Score increases as the disease worsens to a maximum of 38 points.

If chest radiography of the patient was not clinically indicated at the time of the clinic visit, the most recent chest radiograph taken within six months was scored in order to avoid additional exposure of patients to radiation.

Respiratory function tests: the forced expiratory volume in one second and forced vital capacity, were performed on all patients over 6 years of age using a portable Vitalograph machine (a single breath wedge bellows spirometer, serial no M3799) and expressed as a percentage of the predicted value for age and sex. Peripheral blood was taken for measurement of $C$ reactive protein, white cell count (measured in an electronic Coulter counter), and measurement of the erythrocyte sedimentation rate by the Westergren method.

Spearman's rank correlation was used to determine the statistical relation between $C$ reactive protein on the one hand and Shwachman score, Chrispin-Norman $x$ ray score, forced expiratory volume in one second, forced vital capacity, white cell count, and erythrocyte sedimentation rate on the other.

\section{Results}

The serum $\mathrm{C}$ reactive protein concentrations in healthy children ranged from $0 \cdot 01-2 \cdot 8 \mathrm{mg} / \mathrm{l}$. Neither 
these values nor their corresponding logarithms were normally distributed so the upper $95 \%$ confidence limit, $1.875 \mathrm{mg} / \mathrm{l}$, was used as the upper limit of the normal range.

$C$ reactive protein concentrations in patients with cystic fibrosis ranged from $0 \cdot 01-304 \mathrm{mg} / \mathrm{l}$, and concentrations were above the normal range for healthy children in 30 of 52 samples ( 20 of 36 patients). Considering only the first specimen taken from each patient, there were high correlation coefficients between $C$ reactive protein on the one hand and Shwachman score $(\mathrm{r}=-0.77 ; \mathrm{p}<0.001)$ (fig 1), Chrispin-Norman $x$ ray score $(\mathrm{r}=0.68$; $\mathrm{p}<0.001)$ and forced vital capacity as percentage of predicted $(\mathrm{r}=-0.781 ; \mathrm{p}<0.01)$ on the other. $\mathrm{C}$ reactive protein was less closely correlated with forced expiratory volume in one second as percentage of predicted $(r=0.54)$. Low correlations were seen between indices of severity of the disease and either white cell count or erythrocyte sedimentation rate. The highest of these was seen between the Shwachman score on the one hand and white cell count $(r=-0.57)$ and erythrocyte sedimentation rate $(r=-0.35)$ on the other.

Although this was not a longitudinal study, five or more serial measurements were made in two patients during the course of respiratory exacerbations (fig 2). In patient 1 , bacterial infection was initially controlled with antibiotic treatment. A period of subsequent clinical stability was then followed by further exacerbation leading to terminal deterioration. Patient 2 had an initial clinical response to

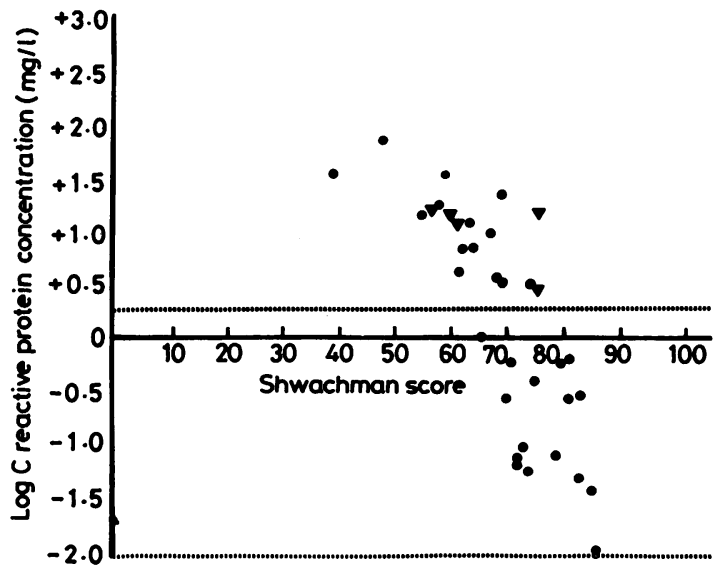

Fig 1 Log serum C reactive protein concentration $(\mathrm{mg} / \mathrm{l})$ plotted against Shwachman score in 52 samples from patients with cystic fibrosis. $\nabla=$ Sample taken during an acute exacerbation of a respiratory infection. The upper $95 \%$ confidence limit for serum $C$ reactive protein concentration in healthy children is indicated by a dotted line.

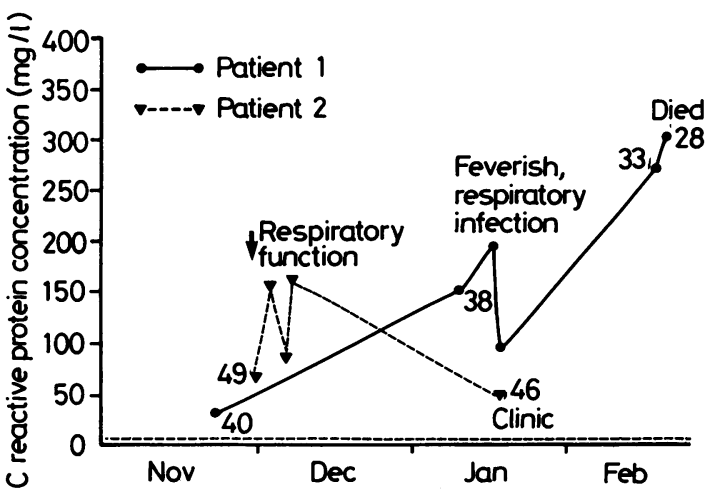

Fig 2 Serum $C$ reactive protein concentration $(\mathrm{mg} / \mathrm{l})$ in two patients with cystic fibrosis. The upper $95 \%$ limit for serum $C$ reactive protein concentration in healthy children is indicated by a dotted line. Numbers adjacent to plotted points represent simultaneous Shwachman scores.

antibiotics but required prolonged antibiotic treatment and physiotherapy before returning to his baseline level of respiratory function at the time of clinic review.

In both patients, bacterial respiratory infections were accompanied by an increase in $\mathrm{C}$ reactive protein concentration and subsequent fall with antibiotic treatment (fig 2).

\section{Discussion}

Cystic fibrosis is a condition in which there is progressive bronchopulmonary damage caused by recurrent respiratory infection of which serum $C$ reactive protein concentrations, as yet unreported in these patients, might provide a useful measure. Raised serum concentrations of $\mathrm{C}$ reactive protein were seen in 20 of 36 patients with cystic fibrosis in this study including all 25 samples from patients with a Shwachman score of 66 or less. A raised concentration of $\mathrm{C}$ reactive protein identified this group with a sensitivity of $100 \%$ and specificity of $78 \%$. Typically a patient with a score of 66 would 'tire easily after exertion, have a daily cough, respirations would be slightly elevated, weight and height between 3rd and 10th percentile and the stools abnormal'. 5

There were highly significant correlations between the serum $\mathrm{C}$ reactive protein concentration and both the Shwachman score and the forced vital capacity as a percentage of predicted. As a good correlation between forced vital capacity and clinical and radiological state has previously been shown, ${ }^{7}$ a rising $\mathrm{C}$ reactive protein appears to be a simple objective index of worsening clinical condition. By 
contrast, white cell count and erythrocyte sedimentation rate were not useful in this respect in this study. The rank correlation between $\mathrm{C}$ reactive protein and the Chrispin-Norman $x$ ray score was also high and significant even though it may have been artificially reduced by the use of the most recent chest radiograph rather than one taken on the same day.

As patients with mild symptoms had abnormal concentrations of $C$ reactive protein we suggest that the serum concentrations may be used as an early marker of deterioration in patients with cystic fibrosis who are not yet severely affected. A high serum $C$ reactive protein concentration may signal the need for more aggressive treatment. Furthermore, our limited experience of serial measurements in cystic fibrosis suggests that a raised concentration of $\mathrm{C}$ reactive protein that is out of proportion to other measures of progression of the disease is likely to represent a bacterial exacerbation (fig 2). The decline in concentrations of $\mathrm{C}$ reactive protein after antibiotic treatment may be useful in monitoring response to treatment in patients with cystic fibrosis in whom this is clinically difficult. ${ }^{2-4}$ Serum $\mathrm{C}$ reactive protein measurement has already been shown to be useful in monitoring the response to antibiotic treatment in immunosuppressed children. ${ }^{8}$ Our results suggest that routine measurement of $\mathrm{C}$ reactive protein in cystic fibrosis may be useful and merits longitudinal study.

We thank Drs CJ Rolles, GM Lewis, and MJ Simpkiss for their permission to study their patients and $\mathrm{Dr} F$ Stevenson for supervising the ELISA measurements of $\mathrm{C}$ reactive protein.

\section{References}

1 Kushner I, Gewurz H, Benson MO. C-reactive protein and the acute phase response. J Lab Clin Med 1981;97:739-49.

2 Pepys MB. C-reactive protein fifty years on. Lancet 1981;i: 653-7.

3 Putto A, Ruskanen O, Meurman O, et al. C-reactive protein in the evaluation of febrile illness. Arch Dis Child 1986;61:24-9.

4 Nudelman R. C-reactive protein in pediatrics. Adv Pediatr 1983;30:517-47.

5 Shwachman H. Long-term study of 105 patients with cystic fibrosis. Am J Dis Child 1958;96:6-15.

${ }^{6}$ Chrispin AR, Norman AP. Systematic evaluation of the chest radiograph. Pediatr Radiol 1974;2:101-6.

7 Mearns MB. Simple tests of ventilatory capacity in children with cystic fibrosis. Arch Dis Child 1968;43:528-39.

* Schofield KP, Voulgari F, Gozzard DI, Leyland MJ, Beeching NJ, Stuart J. C-reactive protein concentration as a guide to antibiotic therapy in acute leukaemia. J Clin Pathol 1982;35:866-9.

Correspondence to Dr CR Kennedy, Department of Child Health, Southampton General Hospital, Shirley, Southampton SO9 4XY.

Accepted 8 March 1988 